\title{
Study on Influencing Factors of Financing Efficiency of Small and Medium-sized Enterprises of New Three Board
}

\author{
Qijun Wu \\ School of Economics, Shanghai University, Shanghai, China
}

Keywords: financing channel; new three board; financing efficiency

\begin{abstract}
This paper focuses on the development status, financing status and financing difficulties of the new three board market, and analyzes the factors that affect the financing efficiency of listed companies of the new three board. This paper first applies the DEA method, taking 173 enterprises listed and perform directional add-issuance financing in the new third board market in 2014 as research sample, analyzes the financing efficiency changes before and after the listing financing of sample companies, and then uses logistic regression model to analyze the relevant factors and the financing efficiency of companies.
\end{abstract}

\section{Introduction}

Recently, the State Council has put forward the slogan of "mass entrepreneurship and innovation" and once again set off a wave of national entrepreneurship. The government also gives strong support to small and medium-sized enterprises in terms of policies, encouraging them to rely on their own advantages in technological innovation to make more favorable development. Compared with other enterprises of the same scale, technical SMEs have higher returns, also with higher risks. More importantly, technical SMEs rely on human capital intensive to achieve rapid development in a very short period of time. It is precisely because of this series of characteristics that it is difficult to satisfy the original financing needs of enterprises by relying solely on other traditional financing channels.

The National Equities Exchange and Quotations (commonly known as the new three board) was formally established in January 2013. On December 31 of the same year, it began accepting listing applications for SMEs nationwide. On November 20, 2015, the China Securities Regulatory Commission released the "On Further Development of the National Equities Exchange and Quotations", which clearly describes the market expectations of the new three board from the perspective of “Top Design”. The establishment of a nationwide SMEs transfer payment system can not only provide the impetus for the development of China's multi-level capital market, but also open up a new pathway for the development of SMEs financing in China, and guide new investment direction for investors, new three board becoming the source for innovative SMEs financing platform and other financial services, which gives full play to the importance of the over-the-counter trading capital market.

\section{Financing Status of New Three Board}

From financing status in 2017, the financing methods selected by the SMEs listed in the new three board include private equity financing, equity pledge financing and private financing of SMEs, of which private equity financing is the main financing method. Equity pledges and private placement of SMEs are still in the initial stages of development, shown in Table 1.

It can be seen that the private placement is the largest. When listed SMEs need large amounts of funds for long-term investment in product development, project construction, and expansion of production scale, they generally recognize targeted capital increases and introduce strategic cooperation. Despite equity diluted ${ }^{[28]}$, partners will not completely lose control of their capital at one time; the time cost of equity pledge financing is the lowest, and funds can be quickly started, mainly to address the temporary shortage of funding for SMEs. With controlling shareholders' 
equity diluted, short-term financing is completed in the shortest time, and requirement of information disclosure is not high; while the private placement of SMEs is not yet complete, the issuing scale is small, and the time cost is higher than equity pledge financing, which is not widely used in listed companies in new three board.

Table 1 Comparison of financing methods of new three board market

\begin{tabular}{|c|c|c|c|}
\hline & Private placement & equity pledge financing & private financing of SMEs \\
\hline $\begin{array}{l}\text { The scale of } \\
\text { fundraising }\end{array}$ & About 50,000,000 & $5,000,000-20,000,000$ & $10,000,000-20,000,000$ \\
\hline Time cost & About 6 months & About 1 month & About 3 months \\
\hline Control right of & diluted & No effect & No effect \\
\hline Composite cost & $\begin{array}{l}\text { Cost of intermediary agency } \\
\text { and information disclosure: } \\
\text { underestimated cost of issued } \\
\text { share price }\end{array}$ & $\begin{array}{l}\text { benchmark interest rate for } \\
\text { loan of the same period of } \\
\text { Central Bank+ floating width }\end{array}$ & $8 \%-10 \%$ \\
\hline Use of funds & $\begin{array}{l}\text { The use shall be clearly } \\
\text { disclosed and supervised. }\end{array}$ & $\begin{array}{c}\text { Freer, used flexibly according } \\
\text { to requirements of } \\
\text { enterprises. }\end{array}$ & $\begin{array}{l}\text { The use shall be clearly } \\
\text { disclosed and supervised. }\end{array}$ \\
\hline
\end{tabular}

\section{Empirical Research}

\subsection{Sample selection}

This paper selects private equity Internet companies released before December 31, 2017, and conducts financing efficiency research based on the 2017 annual report as the source of data. At the same time, in order to ensure the reference of sample, ST companies are excluded because their deteriorated profit margins without the reference significance of basic indicators. According to the above requirements, 132 sample companies are finally selected, and the reference data is financial reports. All other indicators are about rate of change rate, eliminating the impact of absolute value, which can better reflect the actual situation and the actual comparability. However, the enterprise scale index contains the impact of value, so this paper also considers the absolute value of the enterprise scale index

\subsection{Variable declaration}

This paper takes the five indicators of enterprise financing structure, enterprise scale, enterprise growth, profitability and non-debt to evaluate financing efficiency. The impact of efficiency will be taken as influencing factor for financing efficiency, and the asset-liability ratio, growth rate of main business income, enterprise growth, enterprise scale, and non-debt tax shield are selected for analysis and verification.

\subsection{Modeling}

Combined with research results of Gao Shan (2010) on SMEs financing efficiency, this paper takes five indicators of enterprise financing structure, enterprise scale, enterprise growth, profitability, and non-debt to evaluate financing efficiency. The impact of efficiency will be taken as influencing factor for financing efficiency, and indicator system established are shown in Table 2.

Multiple linear regression model is shown in equation (1).

$$
U=\beta_{0}-\beta_{1} T_{1}+\beta_{2} T_{2}+\beta_{3} T_{3}+\beta_{4} T_{4}+\beta_{5} T_{5}+\varepsilon
$$

In equation (1), $\beta 0$ represents the intercept of the entire model, $\beta 1, \beta 2, \beta 3, \beta 4$ and $\beta 5$ represents regression coefficients respectively, both are nonnegative numbers, and $\mathrm{S}$ is residual. 
Table 2 Variables of multiple linear regression model

\begin{tabular}{|c|c|c|}
\hline & Name of variable & Definition of variable \\
\hline \begin{tabular}{|l} 
Dependent \\
variable
\end{tabular} & Financing efficiency(U) & $\begin{array}{l}\text { return on total assets/ weighted average cost of capital } \\
=\text { ROA/WACC }\end{array}$ \\
\hline \multirow{5}{*}{$\begin{array}{l}\text { Independen } \\
\text { t variable }\end{array}$} & asset-liability ratio (T1) & total liabilities /total assets \\
\hline & $\begin{array}{l}\text { growth rate of main } \\
\text { income (T2) }\end{array}$ & $\begin{array}{l}\text { s(current main business income_main business income } \\
\text { of last year)/ main business income of last year }\end{array}$ \\
\hline & enterprise growth (T3) & $\begin{array}{l}\text { (current total assets- total assets of last year )/total } \\
\text { assets of last year }\end{array}$ \\
\hline & enterprise scale (T4) & $\begin{array}{l}\text { data processed with dimensionless method of natural } \\
\text { logarithm of total assets }\end{array}$ \\
\hline & non-debt tax shield (T5) & depreciation/total assets \\
\hline
\end{tabular}

\subsection{Empirical results}

Table 3 Statistical description of sample enterprises

\begin{tabular}{|c|c|c|c|c|c|c|}
\hline variable & $\begin{array}{c}\text { Observed } \\
\text { value }\end{array}$ & maximum & minimum & mean & $\begin{array}{c}\text { Standard } \\
\text { deviation }\end{array}$ & variance \\
\hline $\mathrm{U}$ & 132 & 2.062 & -2.259 & 0.149 & 0.566 & 0.321 \\
\hline $\mathrm{T} 1$ & 132 & 0.962 & 0.005 & 0.248 & 0.198 & 0.037 \\
\hline $\mathrm{T} 2$ & 132 & 48.315 & -0.837 & 2.106 & 6.594 & 43.364 \\
\hline $\mathrm{T} 3$ & 132 & 9.461 & -0.487 & 0.348 & 1.414 & 2.030 \\
\hline $\mathrm{T} 4$ & 132 & 1.012 & 0.000 & 0.490 & 0.191 & 0.035 \\
\hline $\mathrm{T} 5$ & 132 & 0.071 & 0.001 & 0.015 & 0.015 & 0.000 \\
\hline
\end{tabular}

From the sample data in Table 3, it can be clearly seen that in terms of asset-liability ratio, there is large difference in the new three board Internet companies, with maximum value which can reach 0.962 and the minimum value which is only 0.005 , which shows that the selection direction of the new three board Internet companies is different, and some people prefer specific fund acquisition methods; the overall average of 0.149 shows that the sample companies have been leveraged.

Multiple linear regression test is conducted on sample data selected based on requirement of model with SPSS software to obtain results, shown in Table 4.

Table 4 Results of multiple linear regression model

\begin{tabular}{|l|l|l|l|}
\hline Explanatory variable & Regression coefficient & t-test value & Sig \\
\hline C & 0.318 & 1.798 & 0.033 \\
\hline T1 & -1.197 & -4.373 & 0.000 \\
\hline T2 & 0.023 & 2.428 & 0.013 \\
\hline T3 & 0.127 & 2.418 & 0.039 \\
\hline T4 & 0.617 & 2.057 & 0.062 \\
\hline T5 & -8.127 & -2.427 & 0.033 \\
\hline F value & 13.987 & & \\
\hline R2(adjustedR2) & $0.619(0.534)$ & \\
\hline DW statistic & 1.830 & \\
\hline
\end{tabular}

From the results in Table 4, it can be seen that, the overall R2 of the model is 0.619 , and the degree of fitting is high generally. In other words, the overall linearity of the model is relatively good; DW, the value of residual is 1.83 , which is closer to 2 . The autocorrelation of the series basically does not exist; the F statistic of the model is 13.987, which is reasonable, which shows that there is a significant correlation between individuals and model family, that is to say, 
explanatory variables are with strong capability to explain variables. Through the t-test of univariate explanatory results, the t-test value of each variable can well meet the requirements.

The test and t-test results are effective, so the relationship can be obtained, shown in equation (2).

$$
U=0.318-1.197 T_{1}+0.023 T_{2}+0.127 T_{3}+0.617 T_{4}-8.127 T_{5}
$$

\section{Research Results Analysis of Influencing Factors}

The analysis of results shows that there is a positive correlation between the growth rate of enterprise main business income, enterprise growth, enterprise scale, and the financing efficiency of enterprise. In the face of investment objectives of strong profitability, investors will invest funds at lower prices to enterprises with better profitability; enterprise with growth can generally offer investors better growth expectations, and a good company is with more competitive prospects and potential, so for the new three board Internet companies, the growth and probabilities of Internet companies are greater than those of other industries. The good growth means the credit level of enterprises, and in terms of capital efficiency, enterprise with better growth are with more competitive business; a reasonable expansion of enterprise scale can play an important role in improving the financing efficiency of enterprise, larger assets representing the capital level, and the level of financial support can offer more financing channels.

The enterprise scale and comprehensive strength indicate the level of credit, and higher credit levels are the capital. As investors, security is an indispensable part of the overall scale of enterprise.

There is a negative correlation between asset-liability ratio, non-debt tax shield and financing efficiency of enterprise. The higher asset-liability ratio indicates that the debt burden is heavy, which requires the follow-up investment, and has a negative impact on investors' expectations. In order to make up for the risk, investors will definitely demand higher salaries, which leads to the financing costs of enterprise; Non-debt tax shield weakens the incentives for enterprise managers to rely on debt financing to reduce the tax burden. Therefore, when other circumstances are the same, enterprises with more non-debt tax shields have less debt financing and therefore higher financing costs.

\section{References}

[1] Wang Xiaoning, Du Ling, Wang Qitong. Analysis on Financing Efficiency of SMEs Based on Three Phases of DEA Model [J]. Statistics \& Decision, 2016(05): 179-182.

[2] Feng Zhigao, Ma Xinghua. Improve “New Three Board” to Enhance Financing of Small and Medium-sized Technology-based Enterprise [J]. Modern Business, 2010(14):17.

[3] Zhang Xuemei, Sai Zhigang. Review on Connotation and Evaluation of Enterprise Financing Efficiency [J]. Journal of Shandong University of Finance (Bimonthly), 2009 (6): 81-82.

[4] Wang Zheng. The Expansion of "New Three Board": Opportunity for Financing of High-tech SMEs [J]. Anhui Science \& Technology, 2014(10): 26-28.

[5] Wu Chen. The Development of "New Three Board" Market in China and Analysis on Financing of SMEs [J]. Times Finance, 2011 (18): 152-153. 